University of Nebraska - Lincoln

DigitalCommons@University of Nebraska - Lincoln

$1-1973$

\title{
An Incident of Fenthion Mosquito Control and Subsequent Avian Mortality
}

\author{
Robert Seabloom \\ University of North Dakota \\ Gary Pearson \\ USGS Northern Prairie Wildlife Research Center \\ Lewis Oring \\ University of North Dakota \\ James Reilly \\ University of North Dakota
}

Follow this and additional works at: https://digitalcommons.unl.edu/usgsnpwrc

Part of the Other International and Area Studies Commons

Seabloom, Robert; Pearson, Gary; Oring, Lewis; and Reilly, James, "An Incident of Fenthion Mosquito Control and Subsequent Avian Mortality" (1973). USGS Northern Prairie Wildlife Research Center. 113. https://digitalcommons.unl.edu/usgsnpwrc/113

This Article is brought to you for free and open access by the US Geological Survey at DigitalCommons@University of Nebraska - Lincoln. It has been accepted for inclusion in USGS Northern Prairie Wildlife Research Center by an authorized administrator of DigitalCommons@University of Nebraska - Lincoln. 


\title{
AN INCIDENT OF FENTHION MOSQUITO CONTROL AND SUBSEQUENT AVIAN MORTALITY
}

\author{
ROBERT W. SEABLOOM, * GARY L. PEARSON, * ${ }^{*}$ LEWIS W. ORING, * and JAMES R. REILLY*
}

Abstract: Mass mortality among migratory birds at Grand Forks, North Dakota, was attributed to a mosquito control operation employing the insecticide fenthion. The factors involved may have included the toxicity of the pesticide for birds, the method of application and coincidence with the peak of the spring warbler migration.

\section{INTRODUCTION}

A contract mosquito control operation was conducted for the City of Grand Forks, North Dakota, Friday, 23 May 1969 , between 0730 and 1130 hours, on approximately 600 hectares of residential and park areas and adjacent Red River of the North and English Coulee. A helicopter equipped with an $5.5 \mathrm{~m}$ boom fitted with six T-jet size 815 nozzles was employed for the aerial spraying. Undiluted fenthion $(O, O$-dimethyl $O$ - 4-(methylthio)-m-tolyl phosphorothioate) (1) was reportedly applied at the recommended rate of $95.0 \mathrm{ml} / \mathrm{ha}(1.3 \mathrm{oz} /$ acre $)$, and a pressure of $0.84 \mathrm{~kg} / \mathrm{cm}^{2}(12 \mathrm{psi})$ from the aircraft flying at $72 \mathrm{~km} / \mathrm{h}$ just above tree height which varied from $15-23 \mathrm{~m}$.

The same afternoon and on the next 2 days, local residents observed dead and moribund birds. On Monday, 26 May, dead birds which had been collected over the weekend were received by the Biology Department at The University of North Dakota, and a public appeal for additional specimens was issued. A total of 453 birds representing 37 species was received. Found in greatest numbers were warblers and thrushes, especially Tennessee, Vermivora peregrina, (196), yellow, Dendroica petechia, $(88)$, and blackpoll, D. striata, (50) warblers, robins, Turdus migratorius, (17), and Swainson's thrushes, Hylocichla ustulata, (26). Most of the birds (422) were found in areas adjacent to the Red River; 31 others were collected near the English Coulee and elsewhere in the city. It was impossible to ascertain the exact magnitude of the mortality; however, based on an extrapolation of mortalities occurring on areas of known size to the total area treated, it appears that probably 5,000-25,000 birds died.

\section{MATERIALS AND METHODS}

Nineteen warblers and a Swainson's thrush which had been found dead early in the morning of 24 May and frozen immediately were selected for cholinesterase determinations. The birds had been held in home freezers from the time of collection until 28 May and then at -10 $C$ until 3 June. At that time the brains were removed in a frozen state and sent in dry ice to Croswell Henderson, Division of Fisheries Services, Colorado State University, Fort Collins, for cholinesterase assay ${ }^{1}$ which was performed on 7 and 8 June.

\section{RESULTS}

The 20 brains showed very little cholinesterase activity (Table 1 ), a typical finding in cases of fenthion poisoning in birds. ${ }^{2,3}$ Reported average values for several species of passerines, shorebirds

\footnotetext{
- Department of Biology, The University of North Dakota, Grand Forks, North Dakota, U.S.A.

- Northern Prairie Wildlife Research Center, Jamestown, North Dakota.

[1] BAYTEX Liquid Concentrate, Chemagro Corporation, Kansas City, Missouri, U.S.A.
} 
and mourning doves not exposed to fenthion were approximately equivalent to 1.0-1.2 $\mu \mathrm{M}$ acetylcholine bromide hydrolyzed by $2 \mathrm{mg}$ of brain tissue. ${ }^{2}$ The levels of cholinesterase activity observed in this incident are considerably lower than these reported normal values and are comparable to values which Elder and Henderson $^{2}$ found in fenthion poisoning in other species of birds.

TABLE 1. Cholinesterase activity in brain tissue from dead birds, City of Grand Forks, May 1969.

\begin{tabular}{lcll}
\hline Species & Number & Mean* & Range $^{*}$ \\
\hline Swainson's Thrush & 1 & 0.09 & \\
Yellow Warbler & 6 & 0.08 & $0.00-0.36$ \\
Tennessee Warbler & 7 & 0.22 & $0.00-0.68$ \\
Blackpoll Warbler & 6 & 0.35 & $0.00-0.56$ \\
\multicolumn{1}{c}{ TOTAL } & - & & \\
\hline
\end{tabular}

${ }^{*} \mu \mathrm{M}$ acetylcholine bromide hydrolized by $2 \mathrm{mg}$ brain tissue in 30 minutes at $25 \mathrm{C}$.

\section{DISCUSSION}

Fenthion is known to be highly toxic to birds, as indicated by its alternative name "Quelatox" (African weaverbirds are of the genus Quelea), and bird mortalities have been associated with its application for mosquito control at the ultra-low volume rates of $117-234 \mathrm{ml} / \mathrm{ha}^{3.4,6}$ Additional factors in the Grand Forks incident may have included variations in spray droplet size, a cumulative effect of overlapping applications, or areas of high application developing as a result of improper calibration of the spray apparatus or placement of nozzles on the boom. If a pretest of the spray pattern had been conducted, it might have given an indication of calibration errors. There is also the possibility of an uneven application resulting from the use of a highly maneuverable helicopter which could readily vary its air speed or overlap previously treated areas. Furthermore, the spraying was conducted during the peak of the warbler migration, therefore exposing a greater number of species and individual birds than at other times of the spring or summer.

We know of few reported incidents of significant avian mortality resulting from the ultra-low volume application of fenthion. Although the evidence is circumstantial, all indications are that the use of this insecticide, the timing of the operation, and possibly the method of application caused the sudden and widespread mortality. As a result of this mortality and bird losses associated with other similar applications, it was recommended that the registration for ultra-low volume aerial application of fenthion be withdrawn." We understand this has been accomplished, though low volume and conventional aerial applications are still approved.

\section{Acknowledgements}

The authors gratefully acknowledge the assistance of Victor A. Blazevic, Bureau of Sport Fisheries and Wildlife, Devils Lake, North Dakota, and the advice of James B. Elder, Bureau of Sport Fisheries and Wildlife, Minneapolis, Minnesota, in investigating the mortality; Croswell Henderson and George Post, Division of Fisheries Services, Colorado State University, Fort Collins, for cholinesterase determinations; and Marvin Dehn, Supervising Sanitarian, City of Grand Forks, and John L. Pearson, Chemagro Corporation, Fargo, North Dakota, for information on the application of fenthion. Myron Swenson and Paul Springer, Northern Prairie Wildlife Research Center, Jamestown, North Dakota, provided valuable assistance in identifying the birds. 


\section{LITERATURE CITED}

1. AUGUSTINSSON, KLAS-BERTIL. 1957. Assay methods for cholinesterase. VI. Methods based upon chemical determination of unreacted acetylcholine. pp. 43-47 in Methods of Biochemical Analysis, ed. by D. Glick. vol. 5.

2. ELDER, J. B., and C. HENDERSON. 1969. Field appraisal of ULV Baytex mosquito control applications on fish and wildlife. Spec. Rep. U.S. Fish and Wildl. Serv. and Ohio Dept. Nat. Res. 74 p.

3. KEITH, J. O., and D. B. KNAPP. 1969. Some effects on birds of fenthion used as a mosquito larvicide. Proc. and Papers Thirty-seventh An. Conf. Calif. Mosquito Control Assn. 4 p.

4. SMITHSONIAN INSTITUTION, Center for Short Lived Phenomena. 1969. Massachusetts bird kill. Event Information Rep. 87-69.

5. TUCKER, R. K., and D. G. CRABTREE. 1970. Handbook of toxicity of pesticides to wildlife. U.S. Dept. Interior, Fish and Wildl. Serv., Bur. Sport Fish. and Wildl. Res. Pub. No. 84.

6. U.S. Dept. Interior, Fish and Wildl. Serv. Bur. Sport Fish. and Wildl. 1969. Annual Report. Division of Pesticide Registration. 22 pp. 